\title{
Governance of Forest and Peatland Fire Prevention in Riau Province
}

\author{
Zainal \\ Lecturer at Islamic University of Riau \\ Student of Doctoral Program at Padjadjaran University \\ Email: Zainaluir88@gmail.com \\ Utang Suwaryo \\ Lecturer of University Padjadjaran \\ Bandung, Indonesia
}

\author{
Dede Mariana \\ Lecturer of University Padjadjaran \\ Bandung, Indonesia \\ Samugyo Ibnu Redjo \\ Lecturer of University Padjadjaran \\ Bandung
}

\begin{abstract}
Riau Province has extensive forest resources such as peatland potential. But the forest resources that are the lifeblood of this life have not been managed optimally. Forestry problems in Riau Province have shifted from illegal logging to illegal logging and land tenure by the private sector. These activities cause forest destruction, critical land, and the worst is forest fires that cause smoke haze every year. The author put forward the idea proposed by Smith (2007) that the dimensions of law enforcement and prevention of corruption complement of the concept already proposed by Hayden (1992). This study outlines and explains in detail how governance in forest and peatland fire prevention in Riau Province.
\end{abstract}

Keywords: Governance, actor, law enforcement and corruption prevention

\section{INTRODUCTION}

The case of forest fires and peat in Riau have started happening since 1998 until the year 2016 with status emergency smoke. The impact of the economic losses occurs, ecological and social. Land in Riau was dominated by Palm oil land development of conversion into the most dominant role in the causes of the occurrence of forest fires and peat.

The Ministry of forestry and the environment (KLHK) explained that in 2015 about 2.61 million $\mathrm{Ha}$ of land that burned in the entire territory of Indonesia spread on 32 provinces. A number of fires in the peat of about 869,754 Ha (33 percent) and mineral soil 1,741,657 Ha (67 percent). ${ }^{1}$ [1] The Next area burning in Riau Province covering an area of $186,069 \mathrm{Ha}$ equivalent to 7.13 percent of the total number of area burned nationally, that if elaborated about 107,000 Ha land peat and mineral soil 79,069 Ha. Vast acreage burned is functionality can specify i.e., release of acreage to 43 units of plantation area of 21,410 Hectares, 49 acres unit utilization area $67,557 \mathrm{Ha}, 8$ parcels of land covering an area of $380 \mathrm{Ha}$ units, the strategic areas covering $86,861 \mathrm{Ha}$, and the area of other uses of the area of 9,861 Ha. ${ }^{2}$ The forest fire and land it the appropriate case when entering the dry season.
Of the existing problems, the author wanted to do a critical analysis of a dimension that has been said by Hayden (1992) that mention the dimensions of an actor into the things that affect the governance of the Government. Empirically in the field can be understood that the actor dimensions of law enforcement and corruption prevention dimension according to Smith (2007) as well as the influence of forest fires and peat in Riau Province.

\section{SCOPE OF QUESTION}

The urgency of this study discusses how governance in the prevention of forest fires and peat in Riau Province, The concept of governance in this study because of the similarities between fire prevention substances of peat that is both describe the interactions between actors in its implementation which is composed of Government, the private and the public. Departing from the explanation above, the authors want to restrict this paper studies in two questions, namely:

1) How can governance in the prevention of forest fires and peat in Riau Province?

2) Why the required dimensions of the rule of the law and the dimensions of eradicating corruption in governance for the prevention of forest fires and peat in Riau Province?

\section{DISCUSSION}

Term "government" and "governance" is often considered to have the same meaning, namely how to apply authority in an organization, institution or country. Government or the Government is also the name given to the entity which organizes the powers of Government in a country. The concept of "government" refers to an organization management based on the highest authority (State and Government). The concept of "governance" involving not only Governments and countries but also the role of the various actors outside the State and Government, so that the parties involved are also very spacious (Ganie Rochman,2000:141).

The second concept certainly has very fundamental differences, especially in the involvement and domination of 
the actors. Governance could also be interpreted as the management structure of the regime with a view to strengthening the legitimacy of the Organization of power in the eyes of the public life. Legitimacy is dependent variable produced by effective governance. Governance and decision making are two different entities but in practice, both influence each other. Base the distinction is that governance can be termed as a major policy (metapolicies), or what is called by Kiser and Ostrom (1982) as the constitutional choices.

The actor is the three agencies that interplay with each other as well as running the role each of which consists of the private sector, public sector, and civil society. Government as an institution that has a dominant authority should be able to address the problem of forest fires and peat that is in the province of Riau. That should also work together with the private sector and the community. Because if the forests and peat are guarded so forest fires and peat can be overcome or it could be minimised. Some analysis of the theoretical concepts with the approach to the problems that exist can be authors explain as follows:

A. The Dimensions of the Actor

Talking about the actor certainly will not be in spite of the existence of three stakeholders of mutual interest and interplay with each other. Can the author describe the role of the third dimension, namely:

Figure 3.1 Relations between Sectors

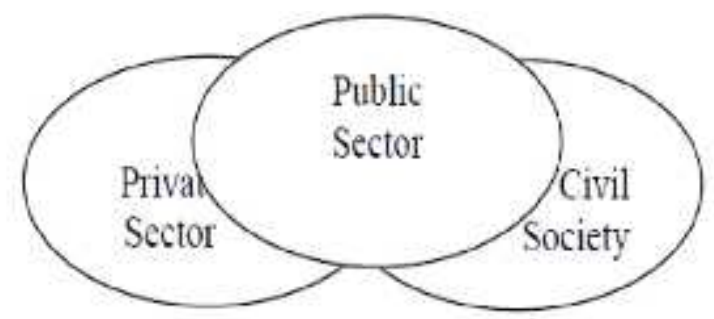

Source: Institution of State Administration (2000:6)

From the picture above can be the author to interpret that the Government no longer is the only institution authorized and dominant but should also involve the private sector and the community, especially in terms of prevention of forest fires and land Peat Moss which is in the province of Riau.

Governance according to Hayden (1992) there are three things that are most affected, namely the structural dimension, the dimension of the actor and the empirical dimension. However, in this paper, the authors discuss only one dimension only i.e. dimensions of actors who focus on discussion on authority and power associated with the private sector and civil society.

The word private sector (private) is often used in a broader sense than the word "privacy" so that almost every private activity is associated with a number of the larger group of Government Weinstein (1971).

Hikam (1993:3) mentioned that civil society is as territories organized life and is characterized by, among others, voluntary, self-generating and self-supporting, independence high dealing with the State and entanglement with the norms or values followed by legal citizens.

About forest fires and peat in Riau Province, the main cause is human-caused 99 percent and only about 1 percent just by natural factors. So can certain forest fires and peat that there was deliberately burned by the stakeholders that there is either by private parties as well as by the community itself.

In 1998 the Center for International Forestry Research (CIFOR) and the International Centre for Research in Agroforestry (ICRAF) conducts research on forest fire and land research results summary: a) motives for economic profit is the main cause of occurrence of fires, b) forest and land, it is manifest in several ways: 1) burn is the easiest and cheap in the land preparation activities, 2) activity illegal wood increase in forest fires in insecurity, 3) fire is the cheapest way and effectively used in social conflict is primarily the problem of land tenure conflicts between different stakeholders. ${ }^{3}$

Forest fires and peat that occurs in Riau were magnitude donated by private parties: with the purpose to minimize operational costs they will use at the time of the opening of the new land which is intended for the manufacture of palm groves. And small enough donated by the community.

Should the Government as an institution that has the power and authority are able to take decisions and make policies as well as strategic measures for the prevention of forest fires and peat in Riau Province. Yet from forest fires and peat that there is presence of lobbying and negotiations conducted by the Government with the private sector. So the society as the weakest domain can only accept against forest fires and land disasters.

Government as an institution that has the power and authority if it is associated with the political approach also can't be separated from the role of the private sector as the domain that is able to finance the political funds to the candidate the Governor in Riau. Because the company is the only domain that has a large amount of capital politics.

According to one of the researchers at Herry CIFOR mentions that it is not easy for a Regents and Governors demanding forest burners, it could be the oil palm, orchards have burned forests, associated with a particular party is stronger in the region, so that The Regent and the Governor is not easy also act must see the political constellation. ${ }^{4}$ The actors work as a form of organized crime. Each group performs the opening act of land will receive a percentage of income alone, the average farmer groups sysop gets the largest portion of income between $10 \%-57 \%$ while farm groups are slashing, cutting down and burning gets the share of income between $2 \%-14 \%$.

There are of course conditions could not be separated from the permissions issued by the Government to private parties to manage forest plantations of Palm or Acacia cultivation. It also aggravated so much acreage be limited production Forest (HPT) converted be Right To attempt (HGU) by existing companies in Riau.

The role of actors in the event of forest fires and land can be understood independently of other actors or relation. 
According to their characteristics, each actor had a certain role that can be played which does not depend on his relations with the other. Social network analysis (social network analysis) understand the role of these actors had a relationship and connection with key actors (Borgatti, 2013). ${ }^{5}$

From the analysis with the approach put forward by Hayden (1992) on the author's tasteless complete if you want to view and analyze forest fires and peat in Riau Province then needs to be complemented with the analysis of the dimensions of enforcement law and corruption prevention dimension expressed by Smith (2007).

In the idea of governance which has been said by Smith (2007) need for law enforcement because of the dimension according to the author why the forest in Riau always just burn among others caused by law enforcement who are less firmly against the perpetrators burning forests and peatlands that are in Riau Province. It was proven by the appearance of the SP3 against 15 companies that are already proven to do the burning land. It is certainly very heartbreaking Riau for the community because it will not have a deterrent effect against giving the perpetrators the forest and burning peat in Riau.

One of the drawbacks of the existing laws in Indonesia is so sharp it down yet so blunt up, meaning that the burners of forest and land in Riau was so difficult to reach by law especially those who have a strong capital (private sector).

Darjono (2003:76) describes the experience of law enforcement against the arsonists and land forest in Riau briefly the steps are as follows:

- The formation of team justice. This team was formed to coordinate the various institutions and information sources that can serve as preliminary evidence, the team was part of the team of Pusdalkarhutla province.

- Data collection. Collection of hot spots obtained from NOAA and other sources of information such as the Ministry of forestry, the Central Bapedal etc, the data in the overlay with the map of land use by Forestry, then retrieved the data company that allegedly doing the burning.

- Flyover. To obtain certainty in the field of data obtained by hot spots do fly over through monitoring by air to match the point coordinates (the result made the news event).

- Ground check. Based on the data above ground check based on the scale of priorities and funds available. For the efficiency of the implementation, the team along with complete justice down expert witnesses, elements of the company, and investigators. In the search for a location suspected of burning the team guided by GPS and data hot spots as well as information flyover. From the experience that exists, it is generally the source data of the three has in common. Data hot spots fly over results information and results of the ground check have the same coordinate points.

- The setting of the SCENE was done at a time when ground check. After burning, we sure do and made a field inspection of the news of the proceedings (BAP)
CRIME SCENE, taking and making COPIES of the sample is required. In addition, it also collected a variety of information including the organization and the officials deemed worthy as witnesses and potential suspects

- Request for the permission of foreclosures evidence to State Court samples taken the seized evidence was made for completeness of the Administration made the application for the permit to the local PN foreclosure.

- $\quad$ Shipping samples. Upon her return to the team from the field, sample accompanied BAP was taken and sent to the laboratory of Bogor Agricultural University (IPB).

- Examination of witnesses. Based on the data of prospective witnesses, undertaken the calling and examination of witnesses in the room investigation located at Bapedal Riau Province.

- Examination expert witnesses. Examination expert witnesses include forest fire expert, expert legal experts, and soil damage the Corporation. The examination was conducted by investigators in Jakarta

- Determination of suspects. Determination of suspects conducted by investigators, in the determination of the team coordinating with investigators justice

- Warrant began investigation (SPDP). After sufficient evidence is obtained and the suspect has been set, the investigators formally deliver in writing to the Attorney General about the commencement of the investigation (SPDP)

- Title of case. The title of the matter carried out by investigators to obtain feedback and refinement of Pulbaket results in filings with securities and making a complete resume with a target of P21.

- Filings with securities. Filings with securities is an activity and gather materials and information which are arranged with attention to norms of administrative investigation based on the CODE of CRIMINAL PROCEDURE.

- The delivery docket. File sent to Kejari through the Police investigation. If the file is considered complete by the Attorney (P21), the task of investigation is finished. But the investigation still performs monitoring and coordination with the Prosecutor's Office in the compose file demands.

Santosa also has a study and analysis in a weak law enforcement in the prevention of forest fires and peat in Riau. Since the year 2012 law enforcement carried out by the Ministry of environment, police, Prosecutors and the courts have done the handling Karhutla but law enforcement agencies especially the judges haven't seen Karhutla case law as an important thing. It is evidenced in the verdict of the judges generally freed the defendant or the defendant's mild rebuke, so that current law enforcement practices have not been able to cultivate a deterrent effect for the perpetrators of the forest and burning peat. ${ }^{6}$ Further Santosa also explains that in general law enforcement Karhutla has yet to contribute 
significantly towards behavior change particularly corporations cause for Karhutla.

The network society Peat Riau (JMGR) also explains that Weak law enforcement in the event of forest fires and peat cause question be to go. The Government should have been more serious and focus on addressing this fire, it gives the best solutions from all aspects arising due to fires in the region of peat, not new doing business after a fire burnout. Because this fire has become a routine agenda in the regions contained the spread peat across in Indonesia. ${ }^{7}$

The elaboration of such empirically explained that the dimensions of the rule of law advanced by Smith (2007) also greatly influence over the occurrence of forest fires and peat in Riau have not been serious law enforcement officers in giving effect deterrent to perpetrators of the forest and burning peat resulted in so difficult a problem to overcome.

\section{The Dimensions of Corruption Prevention}

The wealth of natural resources that are in Riau, Riau, besides making known as rich Voivodeship Indonesia but also even be a problem for the its officers it demonstrated three generations of Riau Governor (Saleh Djasit, Rusli Zainal, and Annas Ma'mun) must feel sleep in detention due to business license utilization of the forest which they spend to the company that resulted in the State's loss of trillions of rupiah.

$\mathrm{KPK}$ as corruption prevention agency in Riau Indonesia set as the most extreme zones and high levels of corruption so as to require that the KPK based in Riau Province.

Made the rescue work network Chairman Ali Forests of Riau (Jikalahari) illustrates that the Governor of Riau as a mini dictator forestry gave permission to anyone who pays. ${ }^{8}$

Further, the corruption eradication Commission (KPK) started the move that has never been done before, namely the investigation of corruption in the forestry sector. Our resource management irregularities not only cause the Country to lose a lot of money but also has a social impact that must be paid by the public each year always inhaling toxic smoke. ${ }^{9}$ The Forestry Sector became a source of massive corruption when Suharto came to power he gave concessions-concessions to friends and colleagues instead of political support that they provide. However, when the last decade during a power down of the Central Government to the local level corruption instead of stopping but instead according to observers of political corruption is becoming more widespread.

Roro Wide Sulistyowati also said that the oil and gas and forestry sector is one sector that is vulnerable to corruption criminal act occurred, specifically the bribes. Riau is one of the central areas of the forestry industry in Indonesia. Forestry can also be expected for the prevention of the occurrence of the corruption of the integrity of the data findings KPK, employers often give money to pelican regulators. ${ }^{10}$ To initiate such activities will also launch programs CCA Professional Integrity (profit) that will control the activities of the businessman. The existence of the program, it is expected that party entrepreneurs committed to not give money or kickbacks, increasing the pelican transparency and accountability of companies and report an indication of criminal acts of corruption, blackmail, illegal charges and others.

From the study of policy corruption point, KPK finds the existence of forest areas in the definition of the ACT. No. 41year 2009, PP. No. 44 in 2009, SK Minister of Forestry No. 32-year 2001, and regulation of the Minister of forestry No. 50 -year 2009 the situation allows the occurrence of favoring treatment which can be utilized to get the perpetrators of illegal logging and illegal mining from lawsuits, or into the crack of wood from illegal logging legislation efforts. The possibility of treatment this siding can also occur from a lack of authority to determine the forest area between the Center and the associated Plan of Spatial Locality. ${ }^{11}$ While the results of the study of the planning System and management of forest area, the KPK finding corruption vulnerability due to uncertainty and uncertainty of space investment, weak regulation and the existence of forest area manager in the field.

\section{CONCLUSION}

From the explanation and elaboration before then in this paper can be summed up briefly two things namely

a. That the role of the actor is the dominant cause of occurrence of forest fires and peat in Riau is primarily the role of the actors who have the power and the authority (Government) that has a wider space when compared to the private sector as well as the community.

b. Forest fires and peat in Riau also could not regardless of empirical fact that law enforcement is still very weak, especially when that did the burning of the enterprise and other dimensions, namely acts of corruption prevention where still half heart performed by KPK because parties involved in granting of permission management of forests in Riau, so much so that expected to work more optimally

\section{References}

[1] Ganie Rochman, 2000. Good Governance Prinsip, Komponen, dan Penerapannya dalam Hak Asasi Manusia (Penyelenggaraan Negara Yang Baik. Komnas Ham; Jakarta.

[2] Hikam, Mohammad, 1999. Demokrasi dan Civil Society, Jakarta; Pustaka LP3ES.

[3] Hayden, Goran. 1992. Governance and The Study of Politics: Governance and Politics in Africa. Boulder, Colorado.

[4] Smith, Brian Clive. 2007. Good Governance and Development. New York. Palgrave MacMillan.

[5] Suyano dkk, 2003. Kebakaran di Lahan Rawa/Gambut di Sumatera; Masalah dan Solusi. Center for International Forestry Reseach; Jakarta.

[6] Lembaga Administrasi Negara dan Badan Pengawasan Keuangan dan Pembangunan, 2000, Akuntabilitas dan Good Governance, Lembaga Administrasi Negara dan Badan Pengawasan Keuangan dan Pembangunan, Jakarta.

[7] (http://www.antaranews.com/berita/489135/indonesia-perlukonsistensi-penegakan-hukum-atasi-kebakaran-hutan)

[8] (http://www.jmgriau.com/2014/11/petaka-di-hutan-dan-lahangambut.html)

[9] (http://www.bbc.com/indonesia/berita_indonesia/2015/10/151

[10] KPK dalam bbc.com

[11] (https://riaucorruptiontrial.wordpress.com/2012/05/01/pember antasan-korupsi-sektor-kehutanan-belum-tuntas/) 